Ђорђе М. Деспић*

Филозофски факултет

Универзитет у Новом Саду
УДК: 821.163.41.09-4 Pavlović M. 821.163.41.09-1 Pavlović M. DOI: $10.19090 /$ gff.2020.1.227- 240

Originalni naučni rad

\title{
ЖРТВЕНИ ОБРЕД У ЕСЕЈИСТИЦИ И ПЕСНИШТВУ МИОДРАГА ПАВЛОВИЋА
}

Павловићева посвећеност кутурно-друштвеним и митско-историјским фазама у развоју људске цивилизације непрестано се прелива са есејистичког на песнички рад, и обрнуто, те се ове праксе код њега тешко могу одвојено посматрати. Укупна Павловићева есејистика садржи у себи више проблемских сегмената, али они нису оделити простори већ саставни делови једне целовитије књижевне и културне мисли која се деценијама код овог аутора конзистентно објављивала, у чему се препознаје тесна повезаност његове есејистике са песничким опусом (касније и романсијерским), што је довело до обликовања једног вишег степена стваралачке кохеренције. Циљ овог рада јесте да, упоредним сагледавањем есејистичких и песничких текстова, укаже на заокупљеност културолошким и антрополошким феноменима у опусу Миодрага Павловића, посебно феноменом жртвеног обреда.

Кључне речи: жртвени обред, есејистика, поезија, интерпретација мит, антропологија, култура

Унутар импресивне есејистике Миодрага Павловића, импресивне и по продукцији, и по ширини тема и интересовања, Павловићеви есеји који се баве митско-антрополошким питањима представљају посебан корпус текстова. Већина књига ове провенијенције Павловић објављује осамдесетих година прошлог века, попут Природног облика и лика (1984), Обредног и говорног дела (1986), Поетике жртвеног обреда (Павловић, 1987), Говора о ничем (1987), Храма и преображења (1989) - да наведемо само неке од најважнијих, чиме та деценија готово у потпуности бива посвећена овој сфери његових есејистичких преокупација. Све ове књиге резултат су исте духовне

\footnotetext{
*djordje.despic@ff.uns.ac.rs

Рад је настао као део научног пројекта 178005 , чији је руководилац проф. др Светлана Томин, а који финансира Министарство просвете, науке и технолошког развоја Републике Србије.
} 
заокупљености - заокупљености човековим културним и духовним коренима. Павловић у њима понајпре развија и надограђује ону линију есејистичке мисли која свој фокус усмерава ка просторима обреда, жртве, мита, ка самом изворишту језичког и културног, као и као оним књижевним делима из светске књижевности која су битно ослоњена на мит. У њима је приметан подстицај који долази из других хуманистичких дисциплина, попут археолошких налазишта древних цивилизација (откриће културе Лепенског вира, рецимо), или пак ширих антрополошких истраживања. Добар део есеја бави се, тако, антрополошким и културним исходиштима која почивају у ритуалу и миту, али и неким универзалним духовним питањима и вредностима (на пример, у Говору о ничем), док ће у Поетици жртвеног обреда аутор посебно настојати да такву формулу митске структуре човека препозна и анализира у књижевним делима. С друге стране, Павловићева поезија готово целим својим током показује велики број кореспондирајућих релација са свим битнијим темама и феноменима који се могу препознати у његовој есејистици. Било да су у питању антички или библијски митови, старословенски простор, српски средњи век и усмена поезија, модерна српска или светска књижевност, песнички опус непрекидно се додирује са његовим есејистичким занимањима, показујући нити једног вишег степена стваралачке кохеренције, при чему поетска манифестација сведочи управо о постојању те критичко-есејистичке и филозофско-културолошке свести свога аутора.

Овај рад свој фокус усмериће ка феномену жртвеног обреда, којим се Павловић понајпре бави у својој Поетици жртвеног обреда, књизи која је од свих других његових митско-антрополошки профилисаних есејистичких дела привукла вероватно највећу пажњу. Идејна интенција ове књиге била је да се на првом месту осветли смисао и објасни функција жртвеног ритуала, затим да се осветли његов значај у даљем развитку људске културе, те укаже на присуство и улогу овог антрополошког феномена у књижевности, како у античкој и библијској, тако и у модерној.

У првом делу књиге аутора интересује сама пракса и смисао жртвеног ритуала који се подразумевао на почетном ступњу настанка цивилизације. ${ }^{1}$ Он

\footnotetext{
1 Поводом ове књиге Владета Јеротић истиче: „У њој је можда највише речи о археологији и о митологији, али она дише и етнологијом, историјом религија и историјом уметности, огледима из књижевности... Ова књига је ипак највише оно што
} 
указује и на онај важан тренутак преокрета у којем су се све високе религије (високе по сублимности), попут хришћанства, ислама, будизма, у раној фази свога деловања почеле да одвајају од жртвеног обреда и постају религије говорништва. Но, жртвени ритуал човеков, према коме је постепено вероватно морао све јачи бивати отпор, представљао је његов дијалог са елементима, и губљењем тог дијалога човек је ,пристао да изгуби свој однос према елементима“ (Павловић, 2000: 10). С друге стране, у контексту археолошких прегнућа и ископина, Павловић подсећа да поверење савременог човека у земљу и воду открива управо његов митски однос према елементима: „Очекује се од земље да поново роди некадашње градове, да врати мртваце, науке, писма, скулптуре, оруђа. Када човек ни би носио у себи архетип земље као прародитељице свега, никада му не би пало на памет да јој се обрати тако како јој се обраћа археолог“ (12). Наглашавајући чежњу за успостављањем контакта са митским, умрлим светом, дакле, аутор археолошким истраживањима не прилази толико са рационалног или научног аспекта, већ из једне поетизоване и заносне митско-антрополошке перспективе.

Однос наших предака према земљи за Павловића је кључан у поступку обреда, и отуда његово настојање да се та релација што детаљније представи. Земља је била онај елемент који омогућава чуда „ницања, растења, цветања, доношења плодова“, што ће наши преци схватати, али и аналошки повезати са родном моћи жене (13). Но, земља није могла родити ни из чега, те се према предању, човеколики и божански Перуша морао делити, тј. комадати, да би се створила жива бића и њихов животни простор:

Делење, раздвајање, имало је у себи једну битно стваралачку функцију уколико се дешавало у митском оквиру првобитности. Схвативши да је и сам „створен“ и да је све што воли и од чега је зависан такође створено, човек је почео да има љубав за стварање, жељу да се оно обнавља, страх да оно може престати, изневерити, оманути. Стварање и створење постали су љубавна брига човекова (Павловић, 2000: 13).

Осим што треба истаћи да последњом реченицом овог цитата Павловић аналитичком и промишљајућем дискурсу готово неприметно даје један поетски тон и шарм, ово је она праситуација од које се мора кренути у

јој наслов казује: песнички, што ће рећи самосвојан и оригиналан приступ, вероватно најстаријем људском феномену: жртвеном обреду“ (Јеротић, 1988: 112). 
разматрање жртвеног ритуала, његове праксе и смисла. ${ }^{2}$ Стога се једна од темељних тачака Павловићевог разматрања феномена жртве заснива на дијалогу који човек води са елементима од којих зависи живот, са земљом и водом. То је најпре дијалог о животу, смрти и поновном рађању, при чему га води и човек као мислилац, и човек као љубавник (20). Отуда се аутор приклања оним схватањима по којима је „успостављање обреда велики стваралачки чин људски““ (21). У том кључу треба читати жртвени ритуал, као чин симболичног дијалога са елементима и састваралачки чин обнове животног циклуса. А антропоморфном схватању земље и аналошким повезивањем са родним атрибутима жене Павловић придружује и промишљање природног облика пећине. Управо у томе леже разлози палеолитске уметности и осликавања унутрашњости пећине. За њу је човек, примећује аутор, везивао материнску и родитељску моћ, те је у њима вршио жртвене ритуале, али и упућивао ликовне поруке земљи, цртајући животиње које су му потребне: „То је био императив његовог магијског хтења, део његовог обраћања у љубави, земљи родитељици животињских врста“ (26).

Степен заинересованости који Павловић показује према културолошким и антрополошким феноменима, и који превазилази границе ове књиге (и присутан је и у Дневнику пене, Природном облику и лику, Говору o Ничем, Храму и преображењу), нужно упућује читаоца Павловићеве есејистике и на његове песничке књиге. У критици је примећено ослањање на мит и митско још од његових првих остварења, а од Млека искони (1962), или од Октава (1957), чак, може се у том смислу говорити и о започињању песничког концепта. Међутим, посматрано из антрополошког угла који Павловић заузима у Поетици жртвеног обреда, код њега се може приметити и онај старији слој који претходи митској причи, и то било у облику односа према елементима, било у присуству знакова жртвеног ритуала. У Октавама, рецимо, доживљај природе митски је, и пантеистички, где субјект се ближи свепрожимајућем јединству са природом и елементима. Однос према природи ту се развија као вид трагања за идентитетом кроз архетипске визије, о чему смо, заједно са функцијом еротске антропоморфизације природе и присуством Емерсонових филозофских схватања, већ писали у Пореклу песме (Деспић,

\footnotetext{
${ }^{2}$ Павловић сумња у тврдњу да су ритуал и мит текли напоредо: „Где има много приче и песме, мало је правог обреда“, јер „већа количина пратећих речи могла је само да распе пажњу свештеника, и да одврати пажњу божанства, или елемента, којем је жртва била упућена“ (Павловић, 2000: 14, 16).
} 
2008). У новијим песмама у прози, пак, у циклусу Дрво (Павловић, 1996), Павловић кроз библијски мит реактуелизује првог човека и његово љубавно општење са природним елементима, чиме се истичу и усложњавају симболичка значења природе и њеног односа према питању човековог идентитета. С друге стране, поверење у земљу као елемент, и наглашавање телурског начела видљиво је код Павловића у већини његових песама у којима се јављају есхатолошка питања, што је посебно наглашено у Великој скитији (1969). У том погледу, треба навести да се и мотив пећине често јавља код Павловића, као на пример у песми „Везиља“ из збирке Велика скитија, у поеми Дивно чудо (1982), или у циклусу песама у прози Пећина из 1996.

Павловићево промишљање жртвеног обреда не може проћи без ослањања на културу Лепенског вира и њених археолошких открића. Осим знакова антропоморфних тумачења функције земље, које је оставио древни човек, он наглашава значај малених облутака, „привилегованих ритуалних предмета“" (Павловић, 2000: 31), који су имали важну сакралну улогу, улогу симболичне заменљивости за живо биће. Отуда су они били пресвучени црвеном бојом која прати рођајне процесе, те су тако престављали симболичну поруку земљи и природи. ${ }^{3}$ У Павловићевој поезији облутак се такође јавља, као и елементи попут камена, ватре, воде, што су све алузије на жртвене ритуале, јављају се богови и богиње, храм, и то посебно у Певањима на виру, збирци директно инспирисаној археолошким открићем Драгослава Срејовића, као и у песми Стари обред из Карика, књизи окренутој, по Славку Гордићу, писцу поговора за Павловићеве Изабране песме, „суштинама и прапочецима“ (Павловић, 1979: 160)․ У Дивном чуду, рецимо, облутак носи симболику жртве и значење обнове и новог живота:

$$
\begin{aligned}
& \text { кроз подземне пећине } \\
& \text { и нове тунеле } \\
& \text { кроз улице пуне наноса и муља } \\
& \text { он гледа у даљини облутак }
\end{aligned}
$$

\footnotetext{
${ }^{3}$ У есеју Питање фантастике из есејистичке књиге Читање замишљеног, Павловић поново говори о праху црвеног окера који се, осим у Лепенском Виру, јавља и на другим локалитетима и у другим културама попут Блиског Истока, код аустралијских урођеника, или у Кини. (Павловић, 1990: 94)

${ }^{4}$ Славко Гордић, Песник повести и културе, поговор за Павловићеве Изабране песме, Рад, Београд 1979, стр. 160.
} 
почиње да се сија

тек испливао из смрти

и у окретању одлучује се

да буде плодан (Павловић, 1982: 39).

С друге стране, камен је не само део обредности, посебно када су у питању споменици мегалити, о којима пише у засебном поглављу Поетике жртвеног обреда, већ постаје и део настанка храмовности (Павловић, 2000: 151). Управо алузија на мегалитску културу и менхире, на Стоунхенџ на пример, јасно је присутна у Павловићевом спеву:

и њему се привиђа сабор

изнад каменог поља

огромна телеса успомена светих

што лактом ослоњене о планину

и голе

чекају да дођу они који су звали

да се почне испочетка

и да се у новом стварању света

употребе други материјали... (Павловић, 1982: 38),

и нешто раније, овога пута експлицитније:

долазе богови камења

оних менхира забодених ко игле

у бицепс плодних њива

и велике плоче

испод којих је био почетак храма (Павловић, 1982: 36).

Отуда се из Павловићевих антрополошко-археолошких есејистичких интересовања намећу питања која бацају јасније светло на кохерентност његовог укупног стваралаштва. Јер, нису ли Павловићева песничка прегнућа у доброј својој мери знак једне потребе да се песнички оваплоте прошла времена? Није ли његов поступак (ре)интерпретације историје и мита израз напора да се дух и говор давнина поетски оживи у новом контексту? Није ли то, дакле, облик песничке археологије која иде у правцу реактуелисања и (ре)креирања древних значења, односно, која жели митско приближити модерном и савременом?

Наравно, Павловић жртвени обред сагледава не само кроз почетно обраћање елементима, већ и кроз обраћање боговима. Стога је Дионис незаобилазан, и аутор подсећа на његов култ који долази из разних културолошких слојева, „малоазијских, егејских, хеленско-балканских“ (Павловић, 2000: 36), те сажето и убедљиво појашњава функцију и смисао 
овог култа, заједно са улогом баханткиња, његових свештеница, и оргијастичног плеса који је сав у функцији телесног буђења земље (37). Импресионира са коликим се степеном упућености, али и луцидног промишљања жртвеног ритуала ${ }^{5}$, Павловић представља на овим страницама: од претпоставки о настајању божанстава у људским представама, пореклу и субини Диониса, до његових свечаности, оргијастичног заноса, феномена промискуитетности и инцестуозности као нечега што несумњиво претходи људској крвној жртви (Павловић, 2000: 40). У најраније тематизације овог феномена Павловић убраја Еурипидову трагедиографију, јер „нема Еврипидове трагедије у којој се не ради о неком виду приношења људске жртве“ (41). Но, Павловић даље наставља с мишљу да је Еурипид слутио или пак знао да жртва мора васкрснути, и да тек тада обред има свој пуни смисао:

Тек пошто је жртва богу принесена бог напушта своју земаљску, људску форму, и јавља се у правом небеском виду. У њему васкрсавају све принесене жртве, - у сталности његовог симболичног вида нестаје полако и потреба за приношењем крвних жртава. Настаје виши степен жртвеног култа, настаје религија која се ослања на уметничко стварање, на ликовне и вербалне сакралне формуле које утврђују и постојање божанства и обезбеђују његово поновно, повратно, благотворно деловање (41).

Теме којима се у својим есејима бави, као и идеје и тезе које у њима износи, или су песнички већ проживљене, или антиципирају будуће стварање. Један од вероватно најранијих примера песничког тематизовања ритуалних и жртвених интересовања Павловић исписује у песми Повратак порочног сина, о оквиру своје збирке Светли и тамни празнищи из 1971. године. Стихови се развијају кроз сведену поетску нарацију, пратећи социјалну и етичку девијацију „порочног сина“, да би се песма привела крају сценом насиља и окрутним чином клања. Последња строфа, међутим, добија значај песниковог коментара који проблемски претходи овим петнаестак година старијим есејистичким текстовима које смо цитирали:

\footnotetext{
5 Ретке су примедбе у освртима на Павловићева промишљања митско-антрополошких тема. Међу њима су и ставови које Бојан Јовановић износи у тексту Песник као антрополог. Он сматра да је у погледу тумачења примарних ритуалних садржаја аутор „мање убедљив“, закључујући на крају да „Павловићева тумачења ритуалних садржаја и аспеката жртвених обреда нису вредносно уједначена, али свежином идеја указују на могућност другачијег разрешавања низа антрополошких питања“ (Јовановић, 1988: 119).
} 
Ноћас још овенчан седи међу оцем и мајком

који се пред суседима хвале повратком сина,

затим га пијаног кољу.

Најдражи син!

Чим је стасао за жртву

дошао је кући да га за ноћ згроме

у весељу и клању;

он покајнички обнавља смисао повратка

и родитељског дома (Павловић, 1971: 32).

Читана у митско-антрополошком коду сцена клања није чин бруталног убиства већ жртвеног ритуала у чијој основи:

лежи метафора плођења и стварања новог живота. Зато је подела улога у жртвовању у схеми оплодитељске радње и породитељског догађаја. Они који треба да принесу жртву, то су пре свега родитељи, не зато да би жртва била посебно страхотна, него, као што је већ речено, да би се људским родитељством подстакло родитељство елемената: мајке-земље, воде-мајке... Сама жртва која се приноси носи у себи метафорику семена. Она има потенцију да се развије као семе, и носи у себи унапред дати лик који треба да се понови и увишестручи ${ }^{6}$ (Павловић, 2000: 56-57).

Отуда синтаксичко и интерпункцијско наглашавање стиха „Најдражи син!“ није ироничан коментар као што можда делује на прво читање, већ она суштина без које се смисао жртвеног ритуала губи.

Тридесетак година касније Павловић објављује у оквиру Песама $о$ детињству и ратовима (1992) и песму Повратак изгубљеног сина, која, у односу на песму Повратак порочног сина, и насловом, и темом, и поступком, успоставља, у антрополошком контексту, једну нарочиту интертекстуалну повезаност. Она се прво очитава у насловима који су варијантни, јер је у обе песме присутан основни мотив повратка сина. Но док је у првој песми јасно присутан и наглашен жртвени ритуал, у другој он је присутан својим одсуством. Смисаона релација која се успоставља одвија се на плану чина жртвовања и очекиваног ефекта, обраћања и одговора, претпоставке и остварења. Другим речима, као да се од друге песме очекују „правоснажне“ последице жртвене функције из прве песме које, међутим, изостају. Уместо плодности, рађања, новог живота, јунак у другој песми доноси само смрт и

\footnotetext{
${ }^{6}$ Подвукао Ђ. Д.
} 
распадање, и непрецизну, порозну границу између живота и смрти. ${ }^{7}$ Као да друга песма у овом специфичном антрополошко-интертекстуалном виду изневерава жртвени ритуал клања сина из прве песме, као да га обесмишљава. И као да је контекст Другог светског рата, иначе владајући контекст Песама о детињству и ратовима, оно што обрће основни смисао и функцију жртве:

Ма колико ми сви били сведоци тога да је агресивност у природи човека нешто реално, и да су облици колективног насиља у наше време, као и раније, веома распрострањени, било као ситуације линча, о којима упечатљиво говори Рене Жирар, или као општепознати облици колективног насиља са политичким или националним мотивима, то са основним мотивом и логиком жртвеног обреда, или приношења дарова, божанствима и елементима, не стоји у вези... (Павловић, 2000: 59-60)

Тамо где симболична карика у жртвеном обреду изостаје, приношење крвне жртве, људске или животињске, свеједно, задржава се на нивоу који је и древном човеку изгледао злочиначким, као и каснијем човеку високих религија. Крвна жртва у том случају значи само заливање земље, без успостављања било каквих трајних митских ликова. Без успостављања тих сталних ликова крвну жртву је немогуће и заменити, онда се она понавља као непрекидно крвопролиће (Павловић, 2000: 42).

Отуда Павловићеви стихови из друге песме у својој интертекстуалној конотативности нуде сугестију о извитопереном и неаутентично оствареном жртвеном ритуалу из прве песме: обред који је требало да буде у функцији обнове и рађања на крају постаје симулакрум и омогућава повампирење, односно нестабилну границу између живота и смрти. Ове две песме у збиља онеобиченој цитатној релацији као да сугеришу да драма и трагичност људског бивања не извиру из саме човекове природе, већ из изгубљеног или ишчашеног обредног додира са природом и елементима.

Сјајан пример тумачења књижевног дела управо са аспекта антрополошко-митског приступа, односно уплива традиције жртвеног ритуала, Павловић демонстрира у Поетици жртвеног обреда у поглављу „Едип - трагедија дословности“. Осим луцидног увиђања како на примеру Софокловог дела жртвено, пророчко и митско прелазе у трагедију и литературу, аутор овде, тумачећи Едипову парадоксално страдалну судбину,

\footnotetext{
7 Овим проблемом Павловић се бави и у свом огледу Народна песма „Браћа $и$ сестра“" (Павловић, 1993)
} 
наглашава оно што ми препознајемо у његовој песми Повратак изгубљеног сина:

У свом дубљем, архаичнијем слоју Едип је пример онога што се догађа кад жртва није добро принесена, и у том лоше обављеном жртвовању налази се језгро читаве клетве коју Едип мора да понесе да би се други поучили... Едип је пример „повратника“ из жртве, нека врста вампира (Павловић, 2000: 205).

Као да hе се ова запажања, у једном модификованом поетском облику слободније асоцијативности, преточити у стихове који у ненаметљивој алузивности упућују на жртвену ситуацију из Повратка порочног сина. Иако ту само жртвовање није избегнуто као у Kpaљy Eduny, као да сама ритуалност није до краја била испоштована, па се „последице“ у симболичкој интертекстуалној каузалности „осећају“ у песми објављеној у збирци из 1992. године:

И он је син. Као потомак се враћа, и све одједном буде старо, пред вратима стоји као авет.

$\cdots$

... као провалник вешт

он лако отвара капију доњег

атара; неопран веслач превози

оно што сам шаље: смрт и распадање.

Враћа се изгубљен син, нити се каје

нити буни, носи своју коб

и полако је другом даје...

...

Опет неки смрад. Нико не разуме

да ту помоћи нема. Остаје се у кужном зраку.

Спрема се победа разблудног сина (Павловић, 1992: 68)

Песма као да не може да измери дубину стварности, и као да је пре представа једне митске свести која не разликује биће од небића, и посматра их као два хомогена дела истог.

8 у једном телевизијском интервјуу емитованом октобра 1998. године на ТВ НС, Павловић говорећи о младалачком читању Бодлерове песме Метаморфоза вампира, признаје да ју је на прави начин схватио тек последњих година, сматрајући да би „можда добар назив песме био Метаморфоза у вампира“. 
Павловићева Orgia profana (Павловић, 1996) експлицитније указује на ишчашеност жртвеног обреда из своје основе. Аутор напомиње да је људска крвна жртва могла бити остварена само уз системско довођење учесника у стање омаме и заноса, помоћу алкохола, рецимо, односно да жртвовање није текло зато што су баханткиње биле у заносу, већ зато што су себе у такав занос осмишљено доводиле. У свом есеју „Изједен овчар“ из Огледа $о$ народној и старој српској поезији, Павловић појашњава ту позицију баханткиња:

Оне нису раскомадавале и жртвовале пастире зато што су биле у фуриозном заносу, него су себе у такав занос доводиле да би један древни, рационалномитски налог могле да изврше (Павловић, 1993: 64).

Трећа песма из циклуса Orgia profana, међутим, како и сам наслов говори, губи ознаку светости и божанског у својој основи, и нуди управо изврнуту логику жртвеног обреда:

\footnotetext{
наступа братија

злопогледна

и наопако обрће

свеопшта допуштења

и занос узима као разлог

прво за дела скврна...

један другог саплићу

и бацају на дно

провалије или јаме

и свечаности кваре (Павловић, 1996: 347).

Из овако наопако постављене жртвене основе, у којој се алузивно могу препознати јаки топоси ратних страхота и трагичних страдања на нашим просторима, ${ }^{9}$ не може произаћи вид плодности, рађања, обнове, већ принцип демонског и деструктивног.

Слично је и са тематизацијом Диониса, баханткиња, оргијастичког заноса и ритуалних светковина. Док ради на Поетици жртвеног обреда Павловић вероватно пише и песму Бакхе из збирке Следства (1985), у чијој се

${ }^{9}$ Не заборавимо да је овај циклус објављен 1996. године, што највероватније значи да је стварносно условљен, будући да је писан у контексту ратних дешавања тих година, при чему не искључујемо могућност да су ови стихови у подједнакој мери и историјско алузивни, и да упућују и на злочине и страдања који су се одвијали за време Другог светског рата.
} 
мотивској подударности налази потврда тадашње песникове духовне преокупације:

Материнска је жртва принесена

у месечарском заносу, син је раскомадан.

Долази Дионис, deus ex machina (Павловић, 1996: 213).

Но, ипак, песник ће овај митско-ритуални чин озбиљније проблематизовати нешто раније, у свом лирском спеву Дивно чудо. За нас је овде посебно важно да истакнемо средишње певање, Месечеву свадбу, које наглашава митолошко-космолошку димензију овог спева, и посебно смисао новог почетка и обнове. У овим стиховима присутна је сва концентрација кључних мотива везаних за жртвени ритуал који Павловић у Поетици тако компетентно разматра, од Диониса, свештеница, жртвеника, храма, до девица, свадбе, плодности, пећине. У циклусу Orgia sacra из 1996. године, међутим, песник ће наглашеније дати ону оргијастичку помаму и занос о којој пише у својој Поетици, где истиче управо смисао и функцију сексуалне помаме: „Земљи треба да се да пример телесног буђења. Истовремено, треба јој дотурити, да тако кажемо, довољно семене течности““ (Павловић, 2000: 37).

Док пише Поетику жртвеног обреда, или је има у свом духовном видокругу, аутор исписује већ наведени оглед „Изједен овчар“, који је датиран јануаром 1981. - октобром 1984. године. Промишљајући првенствено укрштање митолошких елемената са нашом усменом традицијом, аутор се и овде бави жртвеним ритуалом и Дионисовим предањима. У том случају, за нас је сада занимљиво његово подсећање на Овидијеве Метаморфозе, подсећање на „судбину пастира Актеона, који је био претворен у јелена, јер је у шуми био затекао Дијану како се купа, у друштву својих пратилица“ (Павловић, 1993: 63). Управо се ова епизода плодно интертекстуално укршта у 5. песми циклуса Orgia sacra са захтевом жртвеног обреда да „жртва буде питома, да прихвати своју судбину, да се не одупире“ (Павловић, 2000: 46). У песми се на извору појављује јелен, и шумске виле одустају од дева и њиховог насилног жртвовања, и прихватају јелена као вид добровољне жртве: „И усред плеса/ на пропланак је бануо/ јелен/(...) таман су шумске виле/ своју жртву/ хтеле у вир/ да погрузе/ једну од својих/ која није хтела/ од своје воље/(...) сагни се/ спусти још ниже/ своју главу/ сад ниси више/ ловац прелеп/ него удовац/ што тражи своју невесту/ у сенкама врбе(...)“ (Павловић, 1996: 329).

Но, оно што остаје као завршни утисак овог дела јесте запитаност аутора над односом према жртвеном чину и последицама по човека модерног времена: 
Да ли смо одрицањем од логике и праксе жртвеног обреда више добили или смо се више оштетили? То се питање тиче и нашег душевног здравља, и вредновања односа које је успоставила модерна цивилизација, и постаје питање о постојању антрополошких константи и наше зависности од њих. Одвајањем од ритуалне праксе и логике ослободили смо се низа предрасуда и неприхватљивих радњи, но повремено смо окренули леђа симболичним оквирима наше егзистенције у њиховом најопипљивијем виду. Молитва и медитација воде у сасвим апстрактне регионе, а однос према природи и њеним елементима данас јењава, бледи, до потпуне ишчилелости (Павловић, 2000: 61-62).

Притом, Павловић сматра да ће многа будућа књижевност произаћи из ових архаичних слојева људске повести и културе. Стога је за савременог човека који жели да схвати уметност свога доба императив упознавање са симболиком жртвеног обреда и шифром антропоморфног разумевања природе и космоса.

Павловићева читалачка, есејистичка сведочења не треба посматрати издвојено од његовог укупног стваралачког опуса. Његова посвећеност митско-историјским и кутурно-друштвеним фазама у развоју људске цивилизације непрестано се прелива са есејистичког на песнички рад, и обрнуто, те ове праксе тешко могу бити одвојено посматране. Отуда је овај рад ишао управо у правцу доказивања да једна списатељска пракса прати другу, или још прецизније: да једна произилази из друге. Укупна Павловићева есејистика садржи у себи више проблемских сегмената, али они нису оделити простори већ саставни делови једне целовитије књижевне и културне мисли која се деценијама код овог аутора конзистентно објављивала, у чему се препознаје тесна повезаност његове есејистике са песничким опусом (касније и романсијерским), обликујући тиме степен стваралачке кохеренције највишег реда.

\section{Đorđe M. Despić}

\section{THE SACRIFICIAL RITUAL IN ESSEYS AND POETRY OF MIODRAG PAVLOVIĆ}

\section{Summary}

The paper points to a preoccupation with certain cultural and anthropological phenomena in the work of Miodrag Pavlović, especially the phenomenon of the sacrificial ritual, the meaning and function of which the author has primarily dealt with in his Poetics of Sacrificial Ritual. However, this preoccupation with human cultural and spiritual roots is not only a feature of Pavlović's essays, but is also very present in his poetic oeuvre. Hence, this 
paper tries to prove that one writing practice follows another, or more precisely: that one stems from another, showing threads of a higher degree of creative coherence, whereby poetic manifestation testifies to the existence of critical-essayistic and philosophical-cultural consciousness of its author..

Keywords: sacrificial ritual, essay, poetry, interpretation, myth, anthropology, culture

\section{ЛИТЕРАТУРА}

Гордић, С. (1979). Песник повести и културе (поговор). У: Павловић, М. (1979). Изабране песме, Београд: Рад.

Деспић, Ђ. (2008). Порекло песме. Зрењанин: Агора.

Јеротић, В. (1988). Улазак у храм и излазак из њега. Градина 5.

Јовановић, Б. (1988). Песник као антрополог. Градина 5.

Павловић, М. (1971). Светли и тамни празници. Нови Сад: Матица српска.

Павловић, М. (1982). Дивно чудо. Београд: Нолит.

Павловић, М. (1985). Следство. Београд: СКЗ.

Павловић, М. (1990). Читағе замишљьеног. Нови Сад: Братство-јединство.

Павловић, М. (1992). Песме о детињству и ратовима. Београд: СКЗ.

Павловић, М. (1993). Огледи о народној и старој српској поезији. Београд: CK3.

Павловић, М. (1996). Изабране и нове песме. Београд: Просвета.

Павловић, М. (2000). Поетика жртвеног обреда. Београд: Просвета. 